\title{
Faktor-Faktor yang Mempengaruhi Terjadinya Kekurangan Energi Kronik pada Ibu Hamil
}

\author{
Lilis Suryani $^{1,2 *}$, Merisa Riski ${ }^{3}$, Rini Gustina Sari ${ }^{4}$, Heru Listiono ${ }^{5}$ \\ 1,3,4,5 Universitas Kader Bangsa, Jln HM Ryacudu No 887 Ulu Palembang Sumatera Selatan \\ ${ }^{2}$ UPTD Puskesmas Pegayut, Jl. Raya Desa Pegayut Kecamatan Pemulutan, Ogan Ilir, Sumatera Selatan \\ *Correspondence email: umireynand15@gmail.com
}

\begin{abstract}
Abstrak. Kekurangan Energi Kronis pada ibu hamil merupakan suatu keadaan ibu kurangnya asupan protein dan energi pada masa kehamilan yang dapat mengakibatkan timbulnya gangguan kesehatan pada ibu dan janin. Tujuan penelitian ini adalah ingin mengetahui faktor-faktor yang mempengaruhi terjadinya Kekurangan Energi Kronis pada ibu hamil. Penelitian ini merupakan survei analitik dengan desain penelitian cross sectional, penelitian dilakukan pada bulan Juni - Agustus Tahun 2020 di Puskesmas Pegayut Kecamatan Pemulutan Kabupaten Ogan Ilir Sumatera Selatan, Populasi pada penelitian ini yaitu seluruh ibu hamil yang melakukan pemeriksaan ANC di Puskesmas Pegayut pada tahun 2019 yang berjumlah 369 orang dan Sampel yang digunakan pada penelitian ini adalah seluruh populasi yang berjumlah 369 orang, analisa data menggunakan analisis univariat (proporsi), bivariat (uji chi square) dan multivariat (regresi logistik). Hasil analisis menunjukkan bahwa usia ibu jarak kehamilan ( $\mathrm{p}$ value:0,000) dan paritas ( $\mathrm{p}$ vaue:0,000) memiliki hubungan signifikan dengan terjadinya kekuarangan energi kronik, sedangkan usia ibu hamil ( $\mathrm{p}$ value:0,147) tidak memiliki hubungan yang signifikan dengan terjadinya kekuarangan energi kronik. Berdasarkan model akhir analisis multivariat variabel yang paling besar pengaruhnya terhadap kekurangan energi kronik adalah variabel jarak kehamilan. Diharapkan kepada ibu hamil agar melakukan pemeriksaan kehamilan secara rutin minimal 4 kali selama kehamilan untuk menmantau kesehatan ibu dan bayi sehingga mencegah terjadinya komplikasi kehamilan dan persalinan.
\end{abstract}

Kata kunci: Energi; Hamil; Jarak; Kronik; Paritas; Usia

\begin{abstract}
Chronic Energy Deficiency in pregnant women is a condition of the mother's lack of protein and energy intake during pregnancy which can cause health problems for the mother and the fetus. The purpose of this study was to determine the factors that influence the occurrence of chronic energy deficiency in pregnant women. This research is an analytical survey with a cross sectional research design, the study was conducted in June - August 2020 at the Pegayut Public Health Center, Pemulutan District, Ogan Ilir Regency, South Sumatra. The population in this study were all pregnant women who carried out ANC examinations at Pegayut Health Center in 2019 which totaled 369 people and the sample used in this study was the entire population of 369 people, data analysis used univariate (proportion), bivariate (chi square test) and multivariate (logistic regression) analysis. The analysis showed that maternal age at intervals of pregnancy ( $p$ value: 0,000$)$ and parity ( $p$ vaue: 0,000$)$ had a significant relationship with chronic energy deficiency, while the age of pregnant women ( $p$ value: 0.147 ) had no significant relationship with the occurrence of energy deficiency. chronicles. Based on the final model of multivariate analysis, the variable that has the greatest effect on chronic energy deficiency is the pregnancy interval variable. It is hoped that pregnant women should carry out routine pregnancy checks at least 4 times during pregnancy to monitor the health of the mother and baby so as to prevent complications of pregnancy and childbirth.
\end{abstract}

Keywords: Energy; Pregnancy; Distance; Chronic; Parity; Age.

\section{PENDAHULUAN}

Proses kehamilan memegang peranan penting dalam pertumbuhan janin. Berdasarkan Rencana Pembangunan Jangka Menengah Nasional (RPJMN) tahun 2015 sampai tahun 2019, salah satu sasaran pokok ialah meningkatkan status kesehatan gizi Ibu dan anak . Status gizi ibu memegang peranan penting terhadap kelangsungan dan keberhasilan suatu kehamilan. Peranan kecukupan gizi sangat vital, dimulai dari sejak kehamilan trimester pertama hingga seribu hari pertama kehidupan. Gangguan asupan gizi pada masa tersebut dihubungkan dengan risiko terjadiInya penyakit kronis pada masa dewasa. (RI, 2015)

Gangguan gizi pada ibu hamil yang paling sering terjadi adalah Kekurangan Energi Kronis (KEK). Kekurangan Energi Kronis pada ibu hamil merupakan suatu keadaan ibu kurangnya asupan protein dan energi pada masa kehamilan yang dapat mengakibatkan timbulnya gangguan kesehatan pada ibu dan janin. Ibu hamil yang berisiko mengalami kekurangan energi kronis dapat dilihat dari pengukuran lingkar lengan atas (LILA) yang kurang dari $23,5 \mathrm{~cm}$. Kekurangan energi kronis pada ibu hamil dapat menyebabkan risiko terjadinya anemia, pendarahan, berat badan ibu tidak bertambah secara normal, terkena penyakit infeksi, dan menjadi penyebab tidak langsung kematian ibu, sedangkan pengaruh kekurangan energi kronis terhadap proses persalinan dapat mengakibatkan persalinan sulit dan lama, persalinan prematur iminnen (PPI), pendarahan post partum, serta peningkatan tindakan sectio caesaria. Kekurangan energi kronis pada ibu hamil juga dapat menyebabkan intrauterine growth retardation (IUGR) atau bahkan intrauterine fetal death (IUFD), kelainan kongenital, anemia serta lahir dengan 
berat badan lahir rendah (BBLR).(Utami, Setyawati, \& Ariendha, 2020)

Berdasarkan data dari World Health Organization (WHO) pada tahun 2016, ibu hamil yang menderita KEK yaitu sebanyak 629 ibu (73,2 persen) hingga dari seluruh kematian ibu dan memiliki risiko kematian 20 kali lebih besar dari ibu dengan LILA normal (Wikipedia, 2017). Begitu juga data dari Global Health Obsevatory (WHO, 2016) menyatakan bahwa Hasil Survei Pemantauan Status Gizi yang dilakukan oleh Direktorat Jendral Kesehatan Masyarakat menunjukkan bahwa Indonesia memiliki prevalensi kejadian KEK pada tahun 2017 sebesar 14,8 persen. Berdasarkan data riset kesehatan dasar yang dilakukan oleh Badan Penelitian dan Pengembangan Kesehatan tahun 20172018 prevalensi KEK pada ibu hamil di Indonesia sebesar 17,3 persen dan prevalensi anemia pada ibu hamil sekitar 48,9 persen (WHO, 2016).

Data Propinsi Sumatera Selatan ibu hamil yang menderita KEK tahun 2015 sebanyak 1097 orang $(9,1$ persen), tahun 2016 sebanyak 1.295 orang (11,2 persen), tahun 2017 sebanyak 1.357 orang (12,1 persen), dan tahun 2018 sebanyak 1.407 (15,7 persen). Tahun 2015 sampai 2018 mengalami peningkatan yang signifikan sebesar 3,6 persen sehingga KEK merupakan permasalahan mendasar yang perlu mendapatkan penanganan yang lebih baik, mengingat status kesehatan ibu hamil sangat menentukan dalam penurunan Angka Kematian Ibu (AKI) dan Angka Kematian Bayi (AKB). (Dinkes, 2017)

Berdasarkan penelitian yang dilakukan oleh Fitriana 2016 menunjukkan hasil analisis antara jarak kehamilan dengan kejadian KEK dapat diketahui bahwa ibu hamil dengan kondisi KEK ada sebanyak 6 responden (50 persen) dengan jarak kehamilan dekat atau $<2$ tahun, sedangkan pada ibu hamil yang tidak KEK dengan jarak kehamilan dekat sebanyak 2 responden (8,3 persen). Pada ibu hamil dengan kondisi KEK dengan jarak kehamilan jauh atau $>2$ tahun sebanyak 6 responden ( 50 persen), sedangkan pada ibu hamil yang tidak KEK ada sebanyak 22 responden $(91,7$ persen). Hasil analisis dengan uji statistik menggunakan uji Fisher's Exact dan perhitungan nilai Odds Ratio (OR) dengan taraf kepercayaan (IK) 95 persen menunjukkan hubungan yang signifikan antara jarak kehamilan dengan kejadian KEK pada ibu hamil $(\mathrm{p}=0,009)$. Nilai $\mathrm{OR}=11,0 \quad(\mathrm{IK}=1,7-69,0)$ menunjukkan bahwa probabilitas kejadian ibu hanil KEK dengan jarak kehamilan dekat 11 kali lebih tinggi daripada ibu hamil tidak KEK.(Fitriana Dyah, 2016)

Penelitian yang dilakukan oleh Sundari (2019) menunjukkan hasil bahwa dari 72 orang ibu hamil yang mengalami KEK terdapat 6 orang $(8,3$ persen $)$ yang berusia $<20$ tahun atau $>35$ tahun atau masuk dalam kategori usia beresiko tinggi, dan sebanyak 66 orang (91,7 persen) yang berusia 20-35 tahun atau kategori tidak beresiko, jadi terdapat hubungan antara umur ibu hamil dengan kejadian KEK.(Sundari, 2019)

Hasil penelitian Ekowati (2019) menunjukkan bahwa ibu hamil yang mempunyai paritas lebih dari 4 orang lebih beresiko KEK dibandingkan dengan ibu yang mempunyai paritas kurang dari 4 orang, sedangkan menurut Puji E, dkk (2007) paritas merupakan salah satu faktor penyebab terjadinya KEK pada ibu hamil.(Ekowati, 2019)

Irianto (2019) memaparkan dampak yang terjadi pada ibu hamil dengan kekurangan asupan gizi berhubungan dengan KEK yaitu pengaruh terhadap ibu,janin dan persalinan.Dampak KEK terhadap ibu : menyebabkan terjadinya resiko komplikasi seperti anemia, perdarahan, komplikasi persalinan, mudah lelah. Kekurangan asupan gizi pada trimester pertama akan beresiko bayi lahir secara prematur, kematian janin,kelainan sistem syaraf pusat dan kekurangan energi di trimester dua dan tiga akan menghambat pertumbuhan janin dalam kandungan. Dampak terhadap janin : kekurangan gizi pada ibu hamil dapat mempengaruhi proses pertumbuhan janin dan dapat menyebabkan lahir premature, bayi lahir mati,kematian neonatal, cacat bawaan, anemia pada bayi, Berat Badan Lahir Rendah (BBLR). Dampak terhadap persalinan : pengaruh saat persalinan seperti persalinan sulit dan lama, persalinan sebelum waktunya, perdarahan setelah persalinan, resiko lahir dengan operasi.(Oktadianingsih, Irianto, Chandradewi, \& Jaya, 2019)

Yulianti (2018) hasil penelitian menunjukkan pelaksanaan tindakan yang dilakukan untuk mencegah terjadinya KEK yaitu menyarankan untuk melakukan pemeriksaan kehamilan secara rutin untuk mendeteksi kekurangan gizi, menjelaskan dampak yang terjadi akibat kekurangan energi kronik, menjelaskan pada ibu hamil pentingnya mengkonsumsi makanan bergizi untuk menunjang kesehatan ibu dan janin.(Yulianti \& Sari, 2018)

Nuradhiani (2018) memaparkan hasil penelitian mengenai pemanfaatan pelayanan ANC (Antenatal Care) yang baik dapat meminimalisir terjadinya KEK karena antusias ibu hamil dalam memeriksakan kehamilan di fasilitas pelayan di lingkup Puskesmas maupun posyandu. Sehingga permasalahan saat kehamilan dapat dicegah atau ditanggulangi lebih dini dengan pemberianasupan makanan untuk memenuhi kebutuhan gizi ibu dan janin.(Nuradhiani, Briawan, \& Dwiriani, 2018)

Beberapa faktor risiko yang dapat mempengaruhi asupan energi dan dan protein pada ibu hamil antara lain umur, jumlah paritas, jarak kehamilan, status gizi, tingkat pendidikan, status ekonomi dan frekuensi ante natal care (ANC). (Ekowati, 2019)

Hasil penelitian Anisa ( 2014) menyatakan bahwa secara statistik terdapat hubungan yang bermakna antara jarak kehamilan dengan KEK dengan nilai $\mathrm{p}=0,009$. Jarak antara kehamilan yang baik untuk menjaga 
kesehatan ibu dan anak sebaiknya $\geq 2$ tahun. (Novitasari, Wahyudi, \& Nugraheni, 2019)

Berdasarkan hasil studi pendahuluan di Kabupaten Ogan ilir didapatkan data tahun 2019 dengan 25 Puskesmas terdapat 708 angka kejadian ibu hamil KEK dari 10.402 ibu hamil (6,6 persen), dengan dua Puskesmas dengan angka tertinggi yaitu Puskesmas Indralaya 112 angka kejadian dan Puskesmas Pemulutan dengan 84 angka kejadian, sedangkan Puskesmas Pegayut berada diurutan ke 13 dengan angka kejadian 21 dari 369 ibu hamil.(Dinkes, 2019)

Tujuan penelitian ini adalah ingin mengetahui faktor-faktor yang mempengaruhi terjadinya kekurangan energi kronik pada Ibu hamil.

\section{METODE}

Penelitian ini merupakan survei analitik dengan desain penelitian cross sectional, penelitian dilakukan pada bulan Juni - Agustus Tahun 2020 di Puskesmas Pegayut Kecamatan Pemulutan Kabupaten Ogan Ilir Sumatera Selatan.

Variabel independen dalam penelitian ini adalah usia ibu : ideal (jika usia ibu 20 tahun s.d 34 tahun) dan tidak ideal (jika usia ibu $<20$ tahun atau $\geq 34$ tahun), jarak kehamilan : dekat (jika jarak kehamilan $<2$ tahun) dan jauh (jika jarak kehamilan $\geq 2$ tahun) dan paritas : berisiko ( jika anak $>2$ orang) dan tidak beresiko (jika anak $\leq 2$ orang).

Kemudian variabel dependennya adalah kekurangan energi kronik : KEK (Jika Lila Ibu $\leq 23,5$ $\mathrm{cm}$ ) dan Tidak KEK (Jika Lila Ibu > 23,5 cm).

Populasi pada penelitian ini yaitu seluruh ibu hamil yang melakukan pemeriksaan ANC di Puskesmas Pegayut pada tahun 2019 yang berjumlah 369 orang dan Sampel yang digunakan pada penelitian ini adalah seluruh populasi yang berjumlah 369 orang.

Pada penelitian ini pengumpulan data dilakukan dengan cara mengumpulkan data sekunder. Data skunder di peroleh dengan cara menggunakan checklist dengan mengambil data di rekam medis untuk melihat faktor faktor yang mempengaruhi kejadian KEK di Puskesmas Pegayut Kecamatan Pemulutan Kabupaten Ogan Ilir.

Data diolah dengan program SPSS 22.0 for windows. Analisis data menggunakan analisis univariat, bivariat dan multivariat. Analisis univariat untuk melihat distribusi frekuensi dan proforsi masing masing faktor faktor yang termasuk dalam penelitian.(Hastono, 2001)

Analisis bivariat untuk mengetahui hubungan variabel independent dan dependent sekaligus untuk melakukan identifikasi variabel yang bermakna dengan dilakukan Uji Chi-Square, dengan menggunakan perangkat lunak program SPSS dengan batas kemaknaan $\alpha: 0,05$ keputusan hasil statistic di peroleh dengan cara membandingkan nilai $\mathrm{p}$ ( $\mathrm{p}$ value) dengan nilai a.(Hastono, 2001)

Analisis multivariat untuk melihat hubungan antara variabel dependen dengan beberapa variabel independent dan mencari variabel mana yang paling dominan berhubungan kemudian dilakukan Uji interaksi. Dalam analisis multivariate ini digunakan metode analisis regresi logistic tujuanya adalah untuk mendapatkan variabel yang paling dominan, dikarenakan variabel dependen adalah variabel dikotom dan variabel independent kategorikal.(Hastono, 2001)

\section{HASIL DAN PEMBAHASAN Analisis Univariat}

Penelitian ini dilakukan pada 369 responden. Dari hasil penelitian diperoleh bahwa responden yang tidak mengalami KEK terdapat lebih banyak yaitu 348 orang $(94,3 \%)$ di bandingkan dengan responden yang mengalami KEK yang terdapat 21 orang $(5,7 \%$ ). (Tabel $1)$.

Tabel 1. Distribusi Frekuensi Variabel Independen dan Dependen.

\begin{tabular}{|c|c|c|c|}
\hline No & Variabel Penelitian & Total & $\begin{array}{c}\text { Persentase } \\
(\%)\end{array}$ \\
\hline \multirow[t]{4}{*}{1} & Usia Ibu Hamil & & \\
\hline & 1. Tidak Ideal $(<20 />35$ & 325 & 88,1 \\
\hline & Tahun) & 44 & 11,9 \\
\hline & 2. Ideal (20 - 35 Tahun) & & \\
\hline \multirow[t]{3}{*}{2} & Jarak Kehamilan & & \\
\hline & 1. Dekat (<2 Tahun) & 8 & 2,2 \\
\hline & 2. Jauh ( > 2 Tahun) & 361 & 97,8 \\
\hline \multirow[t]{3}{*}{3} & Paritas & & \\
\hline & 1. Risiko (> 2 Orang) & 82 & 22,2 \\
\hline & $\begin{array}{l}\text { 2. Tidak Beresiko }(<2 \\
\text { Orang) }\end{array}$ & 278 & 77,8 \\
\hline \multirow[t]{4}{*}{4} & Kejadian Kekurangn Energi & & \\
\hline & Kronik & 21 & 5,7 \\
\hline & 1. KEK & 348 & 94,3 \\
\hline & 2. Tidak KEK & & \\
\hline
\end{tabular}

Sumber data: hasil penelitian

\section{Analisis Bivariat \\ Hubungan usia ibu hamil dengan kejadian Kekurangan Energi Kronik (KEK)}

Hasil analisis hubungan antara usia ibu hamil dengan kejadian Kekurangan Energi Kronik (KEK) diperoleh bahwa ada sebanyak 20 responden $(6,2 \%)$ yang mengalami KEK dan 305 responden $(93,8 \%)$ yang tidak mengalami KEK dari sejumlah 325 responden usianya tidak ideal. Hasil uji statistik diperoleh nilai $\mathrm{p}=0,490$, maka dapat disimpulkan bahwa secara statistik pada alpa 0,05 tidak ada hubungan yang signifikan antara usia ibu hamil dengan kejadian Kekurangan Energi Kronik (KEK) di Puskesmas Pegayut Kecamatan Pemulutan Kabupaten Ogan Ilir Sumatera Selatan.

Hasil penelitian ini berbeda dengan penelitian yang lakukan Adriani (2019) hasil uji statistik diperoleh nilai $\mathrm{p}$ value $=0,005(\mathrm{p}<0,05)$ maka dapat disimpulkan ada hubungan yang signifikan antara umur ibu dengan kejadian KEK pada ibu hamil. Dari hasil analisis 
diperoleh pula nilai $\mathrm{OR}=4,08$, artinya ibu hamil dengan umur yang beresiko memiliki peluang 4 kali lebih besar mengalami KEK dibanding kan dengan ibu yang umurnya tidak beresiko.(Suwito \& Susilawati, 2019)

Semakin muda dan semakin tua umur seseorang ibu yang sedang hamil akan berpengaruh terhadap kebutuhan gizi yang diperlukan. Umur muda perlu tambahan gizi yang banyak karena selain digunakan pertumbuhan dan perkembangan dirinya sendiri, juga harus berbagi dengan janin yang sedang dikandung. Sedangkan untuk umur tua perlu energi yang besar juga karena fungsi organ yang melemah dan diharuskan untuk bekerja maksimal, maka memerlukan tambahan energi yang cukup guna mendukung kehamilan yang sedang berlangsung. Sehingga usia yang paling baik adalah lebih dari 20 tahun dan kurang dari 35 tahun, dengan diharapkan gizi ibu hamil akan lebih baik.(Suwito \& Susilawati, 2019)

Berdasarkan buku Gizi Ibu dan Anak yang dikarang oleh Paramashanti, BA ( 2019) mengatakan bahwa Ibu hamil yang usianya kurang dari 20 tahun memiliki tingkat risiko kehamilan yang sangat tinggi. Risiko itu bisa terjadi terhadap dirinya sendiri maupun terhadap bayi yang dikandungnya. Resiko yang tinggi ini bisa terjadi karena pertumbuhan linear atau tinggi badan, pada umunya baru selesai pada usia 16-18 tahun. Pertumbuhan itu kemudian dilanjutkan dengan pematangan pertumbuhan rongga panggul beberapa tahun setelah pertumbuhan linear selesai, dan pertumbuhan linear itu selesai pada umur sekitar 20 tahun. Akibatnya, seorang ibu hamil yang usianya belum menginjak 20 tahun, mungkin saja akan mengalami berbagai komplikasi persalinan, serta gangguan penyelesaian pertumbuhan optimal. Hal ini dikarenakan, proses pertumbuhan dirinya sendiri memang belum selesai, serta karena berbagai asupan gizi tidak atau belum mencukupi untuk memenuhi kebutuhan dirinya yang memang masih tumbuh, sedangkan seorang perempuan yang mengalami kehamilan pertama pada usia 35 tahun lebih, juga amat beresiko. Pada usia lebih dari 35 tahun, seorang yang mengalami kehamilan akan lebih mudah terserang penyakit. Organ kandungan pada perempuan itu kan semkin menua, serta jalan lahir semakin kaku, Pada Usia lebih dari 35 tahun, ada resiko untuk mendapatkan anak cacat, serta terjadi persalinan macet, dan perdarahan pada ibu hamil akan terbuka lebih besar. (Paramashanti, 2019).

\section{Hubungan jarak kehamilan dengan kejadian Kekurangan Energi Kronik (KEK)}

Hasil analisis hubungan antara jarak kehamilan dengan kejadian Kekurangan Energi Kronik (KEK) diperoleh bahwa ada sebanyak 5 responden $(62,5 \%)$ yang mengalami KEK dan 3 responden $(37,5 \%)$ yang tidak mengalami KEK dari sejumlah 8 responden yang jarak kehamilanya dekat. Hasil uji statistik diperoleh nilai $\mathrm{p}=0,000$, maka dapat disimpulkan bahwa secara statistik pada alpa 0,05 ada hubungan yang signifikan antara jarak kehamilan dengan kejadian Kekurangan Energi Kronik (KEK) di Puskesmas Pegayut Kecamatan Pemulutan Kabupaten Ogan Ilir Sumatera Selatan. Dari analisis diperoleh pula nilai OR : 35,938 artinya ibu yang jarak kehamilannya dekat mempunyai peluang 35,938 kali lebih besar untuk mengalami KEK dibandingkan dengan ibu yang jarak kehamilannya jauh.

Hasil penelitian ini berbeda dengan penelitian yang lakukan Yuliastuti 2014 yang menemukan tidak ada hubungan yang signifikan antara jarak kehamilan dengan kejadian Kekurangan Energi Kronik (KEK). Jarak kehamilan yang pendek dapat berakibat pada kualitas janin atau anak yang rendah dan juga kesehatan ibu, Konsumsi zat gizi yang cukup dan sesuai dengan angka kecukupan gizi yang dianjurkan untuk setiap individu akan mengakibatkan status gizi yang baik pada seseorang. Sebaliknya jika konsumsi zat gizi berlebih atau kekurangan akan menimbulkan status gizi lebih atau kurang pada seseorang. Tingkat kecukupan energi dan zat gizi secara langsung dipengaruhi oleh konsumsi energi dan zat gizi seseorang. (Yuliastuti, 2014)

Berdasarkan buku Gizi Ibu dan Anak yang dikarang oleh Paramashanti, BA (2019), selain kondisi kesehatan si Ibu, jarak kehamilan juga harus selalu di perhatikan oleh seorang perempuan yang sudah pernah mengalami kehamilan, khususnya pada anak yang pertama. Mengapa jarak kehamilan menjadi amat penting bagi seorang ibu hamil karena seorang perempuan yang belum berjarak dua tahun dari kealhiran anak pertamanya, tentu belum siap untuk mengalami kehamilan berikutnya. Selama dua tahun dari kehamilan pertama, seorang perempuan harus benar-benar memulihkan kondisi tubuh serta meningkatkan status gizi yang diasup dalam tubuhnya.(Paramashanti, 2019)

\section{Hubungan paritas dengan kejadian Kekurangan Energi Kronik (KEK)}

Hasil analisis hubungan antara paritas dengan kejadian Kekurangan Energi Kronik (KEK) diperoleh bahwa ada sebanyak 14 responden $(17,1 \%)$ yang mengalami KEK dan 68 responden $(82,9 \%)$ yang tidak mengalami KEK dari sejumlah 82 responden yang paritasnya beresiko. Hasil uji statistik diperoleh nilai $\mathrm{p}=$ 0,000, maka dapat disimpulkan bahwa secara statistik pada alpa 0,05 ada hubungan yang signifikan antara paritas dengan kejadian Kekurangan Energi Kronik (KEK) di Puskesmas Pegayut Kecamatan Pemulutan Kabupaten Ogan Ilir Sumatera Selatan. Dari analisis diperoleh pula nilai OR : 8,235 artinya ibu yang paritasnya beresiko mempunyai peluang 8,235 kali lebih besar untuk mengalami KEK dibandingkan dengan ibu yang paritasnya tidak beresiko.

Hal tersebut didukung dengan penelitian yang telah dilakukan Sumini 2018 bahwa ada hubungan paritas dengan ejadian Kekurangan Energi Kronik (KEK) di BPM Ny. "A" Desa Gombang 
Kecamatan Slahung Kabupaten Ponorogo. (Sumini, 2018)

Dalam hal ini ibu dikatakan terlalu banyak melahirkan adalah lebih dari 3 kali. Untuk paritas yang paling baik adalah 2 kali Jarak melahirkan yang terlalu dekat akan menyebabkan kualitas janin/anak yang rendah dan juga akan merugikan kesehatan ibu, ibu tidak memperoleh kesempatan untuk memperbaiki tubuhnya sendiri karena ibu memerlukan energi yang cukup untuk memulihkan keadaan setelah melahirkan anaknya. Dengan mengandung kembali maka akan menimbulkan masalah gizi bagi ibu dan janin/bayi berikut yang dikandung. Berapa kali seorang ibu pernah melahirkan Bayi (paritas) diukur dalam baik jika2 kali, dan buruk jika $\geq 3$ kali. (Sumini, 2018)
Berdasarkan buku Gizi Ibu dan Anak yang dikarang oleh Paramashanti, BA (2019) bahwa salah satu faktor penting yang dapat mempengaruhi status gizi ibu hamil adalah paritas. Paritas adalah faktor yang sangat berpengaruh terhadap hasil konsepsi kehamilan. Seorang perempuan harus selalu waspada, terutama seorang perempuan yang pernah hamil atau pernah melahirkan anak sebanyak empat kali atau lebih. Kewaspadaan ini di perlukan karena pasti kan ditemui berbagi keadaan seperti ini seorang ibu hamil bisa mengalami kekendoran pada dinding perut dan dinding rahim. Kondisi ini tentumenggelisahkan bagi beberapa perempuan, sehingga hal ini perlu menjadi hal yang diwaspadai. (Paramashanti, 2019)

Tabel 2. Hubungan Variabel Independen dengan Variabel Dependen

\begin{tabular}{|c|c|c|c|c|c|c|c|c|c|}
\hline \multirow[t]{3}{*}{ No } & \multirow[t]{3}{*}{ Variabel Independen } & \multicolumn{4}{|c|}{ Kejadian KEK } & \multirow{2}{*}{\multicolumn{2}{|c|}{ Total }} & \multirow[t]{3}{*}{ Nilai $\mathrm{p}$} & \multirow{3}{*}{$\begin{array}{l}\text { Odd Ratic } \\
95 \% \text { CI }\end{array}$} \\
\hline & & \multicolumn{2}{|c|}{ KEK } & \multicolumn{2}{|c|}{ Tidak KEK } & & & & \\
\hline & & $\mathrm{n}$ & $\%$ & $\mathrm{n}$ & $\%$ & $\mathrm{~N}$ & $\%$ & & \\
\hline \multirow[t]{3}{*}{1} & Usia Ibu Hamil & & & & & & & \multirow{3}{*}{0,490} & \multirow{3}{*}{2,820} \\
\hline & 1. Tidak Ideal & 20 & 6,2 & 305 & 93,8 & 325 & 100 & & \\
\hline & 2. Ideal & 1 & 2,3 & 43 & 97,7 & 44 & 100 & & \\
\hline \multirow[t]{3}{*}{2} & Jarak Kehamilan & & & & & & & & \multirow{3}{*}{35,928} \\
\hline & 1. Dekat & 5 & 62,5 & 3 & 37,5 & 8 & 100 & \multirow[t]{2}{*}{$0,000^{*}$} & \\
\hline & 2. Jauh & 16 & 4,4 & 345 & 95,6 & 361 & 100 & & \\
\hline \multirow[t]{3}{*}{4} & Paritas & & & & & & & & \\
\hline & 1. Risiko & 14 & 17,1 & 68 & 82,9 & 82 & 100 & \multirow{2}{*}{$0,000^{*}$} & \multirow[t]{2}{*}{8,235} \\
\hline & 2. Tidak Beresiko & 7 & 2,4 & 280 & 97,6 & 287 & 100 & & \\
\hline
\end{tabular}

Sumber data: hasil penelitian.

\section{Analisis Multivariat \\ Pemilihan Variabel Kandidat Multivariat}

Pemilihan variabel kandidat dilakukan melalui analisis bivariat. .Hasil uji bivariat yang mempunyai nilai $\mathrm{p} \leq 0,25$ maka variabel tersebut dapat masuk ke dalam model multivariate, sedangkan variabel yang mempunyai nilai $\mathrm{p}>0,25$ tidak di ikutsertakan dalam analisis multivariate. Dalam penelitian ini ada 3 variabel independent yang masuk dalam analisis multivariate yaitu, usia ibu hamil, jarak kehamilan dan paritas, seperti pada table berikut 3 ini:

Tabel 3. Variabel Independent yang Masuk Kandidat Model Multivariat

\begin{tabular}{clc}
\hline No & $\begin{array}{l}\text { Faktor Berpengaruh Terhadap } \\
\text { Kejadian KEK }\end{array}$ & p value \\
\hline 1 & Usia Ibu Hamil & 0,245 \\
2 & Jarak Kehamilan & 0,000 \\
3 & Paritas & 0,000 \\
\hline
\end{tabular}

Sumber data: hasil penelitian

\section{Pembuatan Model Faktor Penentu Terhadap Kejadian Kekurangan Energi Kronik}

Dari hasil analisis regresi logistic pada model akhir (fit model) didapat 2 variabel yang bermakna secara statistic hubunganya dengan kejadian kekurangan energi kronik. Kedua variabel tersebut adalah variabel jarak dan paritas. Kemudian untuk mengetahui variabel mana yang paling dominan pengaruhnya terhadap kejadian kekurangan energi kronik dapat dilihat pada nilai Exp (B). Dari model akhir ternyata variabel yang paling besar pengaruhnya terhadap kekurangan energi kronik adalah variabel jarak kehamilan.

Tabel 4. Model Akhir Regresi Logistik antara 2 Variabel Independen Dengan Kejadian KEK

\begin{tabular}{|c|c|c|c|c|}
\hline Variabel & B & P Wald & OR & $95 \% \mathrm{CI}$ \\
\hline Jarak Kehamilan & 3,932 & 0,000 & 51,025 & $8,857-293,947$ \\
\hline Paritas & 2,292 & 0,000 & 9,898 & $3,393-28,858$ \\
\hline Constant & $-8,368$ & 0,000 & 0,000 & \\
\hline
\end{tabular}

Sumber data: hasil penelitian

\section{Uji Interaksi antar Variabel Independen}

Dari uji interaksi, terlihat tidak ada interaksi antara jarak kehamilan dengan paritas ( $p$ value : 0,173 ). Keadaan semacam ini memberikan petunjuk bahwa hubungan jarak kehamilan dengan kejadian KEK tidak memberikan efek yang berbeda untuk responden yang paritasnya tinggi dan yang paritasnya rendah. 
Lilis Suryani, Merisa Riski, Rini Gustina Sari dan Heru Listiono, Faktor-Faktor yang Mempengaruhi Terjadinya Kekurangan Energi Kronik pada Ibu Hamil

Tabel 5. Uji Interaksi Antara Jarak Kehamilan dan Paritas Terhadap Kejadian Kekurangan Energi Kronik

\begin{tabular}{lccc}
\hline INTERAKSI & $\mathbf{- 2}$ Loglikehood & G & P value \\
\hline Jarak Kehamilan & 119,843 & 41,322 & 0,948 \\
Paritas & 119,843 & 41,322 & 0,532 \\
Jarak*Paritas & 119,843 & 41,322 & 0,173 \\
\hline
\end{tabular}

Sumber data: hasil penelitian.

\section{SIMPULAN}

Hasil analisis menunjukkan bahwa usia ibu jarak kehamilan ( $\mathrm{p}$ value:0,000) dan paritas ( $\mathrm{p}$ vaue:0,000) memiliki hubungan signifikan dengan terjadinya kekuarangan energi kronik, sedangkan usia ibu hamil ( $\mathrm{p}$ value:0,147) tidak memiliki hubungan yang signifikan dengan terjadinya kekuarangan energi kronik. Berdasarkan model akhir analisis multivariat variabel yang paling besar pengaruhnya terhadap kekurangan energi kronik adalah variabel jarak kehamilan.

\section{DAFTAR PUSTAKA}

Dinkes. (2017). Profil Dinas kesehatan Provinsi Sumatera Selatan.

Dinkes. (2019). Profil Kesehatan, Dinas Kesehatan Ogan Ilir.

Ekowati, D. (2019). Paritas> 3 dan Kekurangan Energi Kronik berhubungan dengan Kelahiran Bayi Berat Lahir Rendah di Situbondo. Jurnal MID-Z (Midwivery Zigot) Jurnal Ilmiah Kebidanan, 1(2), 26-29.

Fitriana Dyah, P. (2016). Faktor-Faktor Yang Mempengaruhi Kejadian KEK Pada Ibu Hamil Di Puskesmas Baturaden II Kabupaten Banyumas. Naskah Publikasi.

Hastono, S. P. (2001). Analisis data. Depok: Fakultas Kesehatan Masyarakat Universitas Indonesia.

Novitasari, Y. D., Wahyudi, F., \& Nugraheni, A. (2019). Faktor-Faktor Yang Berhubungan Dengan Kekurangan Energi Kronik (KEK) Ibu Hamil Di Wilayah Kerja Puskesmas Rowosari Semarang. DIPONEGORO MEDICAL JOURNAL (JURNAL KEDOKTERAN DIPONEGORO), 8(1), 562-571.

Nuradhiani, A., Briawan, D., \& Dwiriani, C. M. (2018). Dukungan guru meningkatkan kepatuhan konsumsi tablet tambah darah pada remaja putri di Kota Bogor. Jurnal Gizi dan Pangan, 12(3), 153160.

Oktadianingsih, D., Irianto, I., Chandradewi, A., \& Jaya, I. S. (2019). Penambahan berat badan ibu hamil terhadap berat bayi lahir di kota mataram. Jurnal Gizi Prima (Prime Nutrition Journal), 2(2), 76-85.

Paramashanti. (2019). Gizi Ibu dan Anak.

RI, K. (2015). Rencana Pembangunan Jangka Menengah Nasional (RPJMN) Tahun 2015-20120. Jakarta: Kemenkes RI.

Sumini, S. (2018). Hubungan Paritas dengan Kejadian Kekurangan Energi Kronik (KEK) pada Ibu Hamil Di BPM Ny."A" Desa Gombang Kecamatan
Slahung Kabupaten Ponorogo. Jurnal Delima Harapan, 5(1), 1-11.

Sundari, A. (2019). GAMBARAN FREKUENSI KUNJUNGAN ANC PADA IBU HAMIL DI PUSKESMAS KASIHAN II. UNIVERSITAS ALMA ATA.

Suwito, A., \& Susilawati, S. (2019). Kejadian Kekurangan Energi Kronik (KEK) pada Ibu Hamil. Jurnal Kesehatan, 10(3), 220-227.

Utami, K., Setyawati, I., \& Ariendha, D. S. R. (2020). Kekurangan Energi Kronis Pada Ibu Hamil Trimester I Berdasarkan Usia Dan Graviditas. JURNAL KESEHATAN PRIMER, 5(1), 18-25.

Yulianti, S., \& Sari, N. N. (2018). UPAYA PERBAIKAN GIZI DENGAN PEMBERIAN MAKANAN TAMBAHAN PADA NY. D UMUR 24 TH G1 P0 A0 HAMIL TRIMESTER II DENGAN KURANG ENERGI KRONIS (KEK) DI BPM SATIARMI KOTA BENGKULU TAHUN 2018. Journal Of Midwifery, 6(2), 35-40. Yuliastuti, E. (2014). Faktor-faktor yang berhubungan dengan kekurangan energi kronis pada ibu hamil di Wilayah Kerja Puskesmas Sungai Bilu Banjarmasin. An-Nadaa: Jurnal Kesehatan Masyarakat, 1(2), 72-76. 